\title{
Dolus eventualis jako remedium na braki legislacyjne ustawodawstwa karnego Polski Ludowej 1944-1969 - analiza prawna
}

\section{WPROWADZENIE}

Oparcie odpowiedzialności karnej na zasadzie subiektywizmu stanowi jedno z ważniejszych osiągnięć w rozwoju i ewolucji prawa karnego. Czerpiący z zasad odpowiedzialności deliktowej prawa rzymskiego podział na dolus i culpa, odpowiadający generalnie rozróżnieniu na winę umyślną i nieumyślną, był na przestrzeni wieków przedmiotem licznych opracowań naukowych ${ }^{1}$. Jeśli chodzi o nieumyślność, obecnie posługujemy się dwiema jej podstawowymi formami: lekkomyślnością (luxuria) i niedbalstwem (negligentia), a jeśli chodzi o winę umyślną - zamiarem bezpośrednim (dolus directus) i zamiarem ewentualnym (dolus eventualis $)^{2}$.

I choć wydawałoby się, że różnica między umyślnością a nieumyślnością jest zasadnicza, to na pograniczu tych rodzajów już taka oczywista nie jest. Przyjęcie jednak kwalifikacji czynu jako umyślnego zamiast nieumyślnego, chociażby z zamiarem ewentualnym, rodzi poważniejsze konsekwencje. Problem rozróżnienia luxuria od dolus eventualis sprowadza się w istocie do oceny materiału dowodowego każdego konkretnego przypadku. Pytanie zatem brzmi, czy w warunkach transformacji ustrojowej po 1945 r. w Polsce, czyli powszechnie znanej represyjności ówczesnego wymiaru sprawiedliwości i praktyki „wlewania nowej treści w starą

${ }^{1}$ K. Sójka-Zielińska, Historia prawa, Warszawa 2000, s. 174-175.

${ }^{2} \mathrm{~W}$ nauce oczywiście wyróżnia się jeszcze inne formy zamiaru, np. dolus coloratus, dolus repentinus, dolus preameditatus, dolus generalia. Szerzej: W. Wróbel, A. Zoll, Polskie prawo karne - część ogólna, Kraków 2010, s. 211-213. 
formę przepisów", ta subtelna, aczkolwiek fundamentalna różnica w prawnokarnej ocenie czynu zabronionego była respektowana, a jeżeli nie, to dlaczego? Czy uwzględnienie przez Kodeks karny z 1932 r. (art. 14) godzenia się na możliwości popełnienia umyślnego czynu zabronionego okazało się wówczas zaletą, czy wadą tego aktu i z czyjego punktu widzenia?

Odpowiedź na powyższe pytania badawcze zostanie udzielona z wykorzystaniem metody historycznoprawnej i dogmatycznoprawnej. Pomocniczo zastosowana zostanie również metoda teoretycznoprawna, zwłaszcza w odniesieniu do koncepcji winy w doktrynie prawa karnego.

Podstawę badań stanowią akty prawne z zakresu prawa karnego materialnego obowiązujące w polskim systemie prawnym po 1944 r. Istotne znaczenie dla pracy mają również wybrane przykłady powojennego orzecznictwa Sądu Najwyższego, zwłaszcza w zakresie, w jakim zmieniały rozumienie przepisów przedwojennych. W celu ukazania związku problematyki dolus eventualis z zagadnieniem kodyfikacji prawa karnego materialnego Polski Ludowej w pracy wykorzystano też kolejne projekty kodeksu karnego PRL z lat 1956, 1963 i 1966/68.

\section{O ZAMIARZE EWENTUALNYM W OGÓLNOŚCI}

Dolus eventualis można określić jako „najmłodszą” formę winy umyślnej. Stanowi on bowiem efekt XIX-wiecznej niemieckiej krytyki zamiaru pośredniego (dolus indirectus), którego konstrukcja sięga XII w., a jej autorstwo przypisuje się Bernardowi z Pawii (versanti in re illicita imputantur omnia qua sequitur ex delicto $)^{3}$. Zamiar ewentualny był stosowany w praktyce sądowej II Rzeszy po wejściu w życie ogólnoniemieckiego Kodeksu karnego z 1871 r., choć nie był w tym kodeksie zdefiniowany. Po raz pierwszy dokonano tego dopiero w rosyjskim Kodeksie karnym z 1903 r. ${ }^{4}$ Konstrukcja dolus eventualis została przyjęta w polskim Kodeksie karnym z 1932 r. ${ }^{5}$ Jej istotą było to, że sprawca wprawdzie nie chce popełnić przestępstwa, ale przewiduje taką możliwość i godzi się na nią ${ }^{6}$.

3 A. Marek, Prawo karne, Warszawa 2005, s. 138.

4 „Przestępstwo będzie uważane za umyślne nie tylko, gdy winowajca pragnął jego popełnienia, lecz także gdy świadomie godził się z nastąpieniem skutku, warunkującego przestępność czynu" (art. 48). Kodeks karny z r. 1903 (przektad z rosyjskiego) z uwzględnieniem zmian i uzupetnień obowiazujacych w Rzeczypospolitej Polskiej w dniu 1 maja 1921, Warszawa 1922, s. 17, https:// www.bibliotekacyfrowa.pl/dlibra/publication/50138/edition/50650/ [dostęp: 6.09.2020]. Zob. także A. Dziadzio, Powszechna historia prawa, Warszawa 2008, s. 395.

5 „Przestępstwo umyślne zachodzi nie tylko wtedy, gdy sprawca chce je popełnić, ale także gdy możliwość skutku przestępnego lub przestępności działania przewiduje i na to się godzi” (art. 14). Szerzej: J. Makarewicz, Kodeks karny z komentarzem, red. A. Grześkowiak, K. Wiak, Lwów 1938 (reprint: Lublin 2012), s. 77-80.

${ }^{6}$ Ibidem, s. 77. 
Według doktryny komunistycznej zamiar ewentualny sprowadzał się z kolei do świadomości społecznego niebezpieczeństwa czynu i zgody na jego popełnienie. Takie podejście stanowiło konsekwencję odrzucenia formalizmu (normatywizmu), zarówno w rozumieniu istoty przestępstwa, jak i winy, które to tzw. burżuazyjne prawo - zdaniem marksistów - „odrywało od życia”’. Jak pisał Stanisław Pławski:

[...] normatywne pojmowanie winy łączy się z dyskryminacją człowieka przez sądy państw kapitalistycznych, albowiem pozwala im - na podstawie całokształtu okoliczności sprawy - ocenić w sposób negatywny osobę sprawcy, niezależnie od występującego u niego procesu psychicznego w związku z czynem ${ }^{8}$.

Bez względu jednak na koncepcje widać, że dolus eventualis jako rodzaj oceny subiektywnego nastawienia sprawcy do czynu jest czymś więcej niż lekkomyślnością, i niewątpliwie cechuje się mniejszym ujemnym ładunkiem złej woli niż dolus directus. Wspólnym elementem lekkomyślności i dolus eventualis jest świadomość możliwości popełnienia przestępstwa lub - jak chce doktryna marksistowska świadomość możliwości społecznego niebezpieczeństwa czynu. To, co różni te dwie formy winy, to brak zgody (godzenia się) na to9.

W praktyce zatem - jak trafnie zauważa Andrzej Marek - niezależnie od koncepcji kłopotliwe może być odróżnienie tej formy winy umyślnej od świadomej nieumyślności, czyli właśnie lekkomyślności, przy której sprawca też zdaje sobie sprawę z możliwości popełnienia przestępstwa, ale liczy, że do niego nie dojdzie ${ }^{10}$.

\section{ZAMIAR EWENTUALNY PRZY PRZESTĘPSTWACH PRZECIWKO INTERESOM POLITYCZNYM I GOSPODARCZYM PAŃSTWA LUDOWEGO}

Już od początku funkcjonowania na ziemiach polskich nowej władzy ludowej w działalności legislacyjnej oraz praktyce można było zauważyć znamienne zjawisko. Z jednej strony, polegało ono na lekceważeniu, a w konsekwencji nieprecyzyjnym określaniu strony przedmiotowej przestępstw ${ }^{11}, \mathrm{z}$ drugiej - na podkreślaniu

7 T. Cyprian, Wina w projekcie kodeksu karnego Polski Ludowej, „Nowe Prawo” 1952, nr 10, s. $16-20$.

${ }^{8}$ S. Pławski, Wina jako problem kodyfikacyjny, „Państwo i Prawo” 1951, z. 2, s. 249.

${ }^{9}$ Ibidem.

${ }^{10}$ A. Marek, Prawo karne, s. 140.

${ }^{11}$, ,...] zrównanie górnej granicy sankcji za dokonanie czynu z górną granicą sankcji za jego przygotowanie wskazuje bowiem na to, że ustawodawca praktycznie nie przywiązywał wagi do zaistniałych faktycznie zdarzeń, interesował go jedynie cel i zamiar sprawcy". P. Kładoczny, Prawo jako narzędzie represji w Polsce Ludowej (1944-1956): prawna analiza kategorii przestepstw przeciwko państwu, Warszawa 2004, s. 268. 
znaczenia strony podmiotowej, będącej konsekwencją szeroko pojmowanego zamiaru kontrrewolucyjnego, rodem z ZSRR ${ }^{12}$. Podkreślenia wymaga jednak to, że tego rodzaju podejście oznaczało całkowitą rezygnację z nieumyślnego typu niektórych przestępstw. Skutkowało także szeroką interpretacją dolus eventualis ${ }^{13}$.

Pierwsza sytuacja miała miejsce w odniesieniu do przestępstwa szpiegostwa (art. 90 k.k.W.P. i art. 7 m.k.k. wersja I i art. 8 m.k.k. wersja II) ${ }^{14}$. W doktrynie podkreślano, że rezygnacja z międzywojennej formy nieumyślnej przestępstwa szpiegostwa (art. $10 \S 5$, art. 11, $12 \S 3,18 \S 3$ rozporządzenia Prezydenta Rzeczypospolitej z dnia 24 października 1934 r. o niektórych przestępstwach przeciwko bezpieczeństwu Państwa ${ }^{15}$ ) wynikała z faktu ,iż społeczeństwo jest świadome szkodliwości, znaczenia i przejawów szpiegostwa, a więc nieumyślne przestępstwo tego rodzaju nie występuje [podkr. T.Sz.]"16. To domniemanie świadomości stanowiło jaskrawy przykład instrumentalnego wykorzystania prawa karnego oraz podkreślenie jego represyjnego względem obywateli wymiaru. Był to efekt przyjmowania marksistowskiej koncepcji winy sprowadzającej się do świadomości społecznego niebezpieczeństwa czynu ${ }^{17}$. Ma

${ }^{12}$, ,[...] o ile bowiem ustawodawca przedwojenny dbał przede wszystkim o zachowanie funkcji gwarancyjnej materialnego prawa karnego, o tyle ustawodawca »ludowy« kładł nacisk na specyficznie rozumianą funkcję ochronną prawa. Ochrona interesów państwa, wzorowana na prawie sowieckim, opierała się przede wszystkim na zamiarze i pobudkach sprawcy, a strona przedmiotowa przestępstwa - w odróżnieniu od prawa okresu międzywojennego - schodziła na dalszy plan, co powodowało nawet rozszerzającą interpretację przepisów contra legem”. Ibidem, s. 271.

${ }^{13}$ Ibidem. 253.

14 „Art. 90 § 1. Kto, działając na szkodę Państwa Polskiego, dopuszcza się zbierania lub przekazywania wiadomości, stanowiących tajemnice państwową lub wojskową, przechodzi na stronę nieprzyjaciela lub ucieka zagranicę, podlega karze więzienia od lat 10 do 15 albo karze śmierci" (Dekret Polskiego Komitetu Wyzwolenia Narodowego z dnia 23 września 1944 r. - Kodeks Karny Wojska Polskiego, Dz.U. Nr 6, poz. 27). „Art. 7. Kto, działając na szkodę Państwa Polskiego, gromadzi lub przekazuje wiadomości, dokumenty lub inne przedmioty stanowiące tajemnicę państwową lub wojskową, podlega karze więzienia na czas nie krótszy od lat 5 lub dożywotnio albo karze śmierci" (Dekret z dnia 13 czerwca 1946 r. o przestępstwach szczególnie niebezpiecznych w okresie odbudowy Państwa, Dz.U. 1945, Nr 53, poz. 300). „Art. 8. Kto, działając na szkodę Państwa Polskiego, gromadzi lub przekazuje wiadomość, dokumenty lub inne przedmioty stanowiące tajemnicę państwową lub wojskową podlega karze więzienia lub więzienia dożywotniego albo karze śmierci" (Dz.U. 1946, Nr 30, poz. 192).

${ }_{15}$ Dz.U. 1934, Nr 94, poz. 851.

${ }^{16}$ P. Kładoczny, Prawo jako narzędzie represji..., s. 236; por. M. Siewierski, Mały kodeks karny i ustawodawstwo przeciwfaszystowskie. Komentarz i orzecznictwo, Łódź 1949, s. 47-48.

${ }^{17}$ Doktryna komunistyczna podkreślała, że o ile nie można wymagać powszechnej znajomości ustaw, o tyle sytuacja wygląda inaczej w odniesieniu do świadomości społecznego niebezpieczeństwa czynu. W kontekście domniemania świadomości niebezpieczeństwa przestępstwa szpiegostwa zakrawa na hipokryzję twierdzenie T. Cypriana, że „przypadki, w których sąd uzna, że sprawca tej świadomości nie miał, będą coraz rzadsze w miarę ogólnego podnoszenia kultury i uświadomienia społecznego, ale już sama konieczność rozważenia tego elementu przestępstwa wskazuje na realiza- 
rację Piotr Kładoczny, że takie stanowisko, w połączeniu z „kontrrewolucyjnym zamiarem ewentualnym" promowanym w orzecznictwie ${ }^{18}$ oraz nieprecyzyjną konstrukcją strony przedmiotowej tego przestępstwa, pozwalało na przypisanie go „każdemu lub prawie każdemu” ${ }^{19}$. Z drugą sytuacją, tj. szerokim wykorzystaniem dolus eventualis, mieliśmy do czynienia przede wszystkim na gruncie przestępstwa sabotażu (art. 5 dekretu o ochronie państwa, art. 3 m.k.k.) ${ }^{20}$. Ponownie, przy nieokreślonym pojęciu sabotażu oraz rozciągłej konstrukcji kontrrewolucyjnego zamiaru ewentualnego, przepis ten mógł być zastosowany w każdym przypadku, niezależnie od rzeczywistych pobudek potencjalnego sprawcy (np. chęć zysku) oraz przedmiotów (urządzeń) podlegających zbyciu lub zniszczeniu. W istocie od uznania sądu zależało, kogo uznać za wroga Polski Ludowej²1.

Dolus eventualis był również wykorzystywany do zaostrzenia polityki karnej na gruncie art. 39 m.k.k. (tzw. mały sabotaż w odróżnieniu od dużego z art. 3 m.k.k.) $)^{22}$. W wyroku z 29 marca 1963 r. (IV K 745/62) Sąd Najwyższy stwierdził, że przepisu

cję zasadniczego postulatu socjalistycznej praworządności, jakim jest zerwanie z fikcją powszechnej znajomości obowiązujących ustaw". T. Cyprian, Wina w projekcie kodeksu karnego..., s. 10.

18 Wytyczne Zgromadzenia Sędziów Najwyższego Sądu Wojskowego z 19 grudnia 1952 r. głosiły: „Przedmiotem rodzajowym przestępstwa kontrrewolucyjnego jest Polska Rzeczpospolita Ludowa - państwo demokracji ludowej jako postać dyktatury proletariatu, ustrój polityczny i społeczno-gospodarczy, władza ludowa, podstawy ekonomiczne Polski Ludowej, jej niezawisłość i bezpieczeństwo. Przedmiotowa strona przestępstwa kontrrewolucyjnego obejmuje każdy czyn godzący w rodzajowy przedmiot przestępstwa kontrrewolucyjnego. Podmiotowa strona przestępstwa kontrrewolucyjnego obejmuje zamiar kontrrewolucyjny bezpośredni, a odnośnie niektórych przestępstw kontrrewolucyjnych również zamiar kontrrewolucyjny ewentualny [podkr. T.Sz.]. Podmiotem przestępstwa kontrrewolucyjnego jest wróg Polski Ludowej”. Ibidem, s. 129.

19 Ibidem, s. 236

${ }^{20}$ Postanowienia NSW z 13 IV 1948 r., z 14 IV 1948 r. oraz z 21 VI 1948 r., „Wojskowy Przegląd Prawniczy" 1949, nr 1, s. 179-184, za: P. Kładoczny, Prawo jako narzędzie represji..., s. 221, przyp. 28.

${ }^{21}$ „Dopuszcza się aktu sabotażu nie tylko ten, kto chce swym czynem utrudnić prawidłowe działanie zakładu użyteczności publicznej (zamiar bezpośredni), lecz również ten, kto przewiduje, że czynem swym utrudni prawidłowe działanie zakładu, i na to się godzi (zamiar ewentualny). (N.S.W. 216/13.IV.48r.)”; „Sabotaż nie jest przestępstwem celowym i może być popełniony z zamiarem ewentualnym. Karalność działania określonego w poszczególnych punktach art. 3 dekr. nie jest uwarunkowana żadnym poszczególnym celem i dlatego pobudki działania sprawcy (względy polityczne, jak i np. chęć zysku) są dla kwalifikacji prawnej czynu obojętne (N.S.W. 219/21.VI. 48r.)". M. Siewierski, Maty kodeks karny ..., s. 39.

${ }^{22}$ „Kto w zakładach państwowych lub samorządowych albo działających z udziałem finansowym lub pod zarządem Państwa lub samorządu bądź też prowadzonych przez przedsiębiorstwa państwowe lub samorządowe albo przez instytucje prawa publicznego lub spółdzielnie: 1) ze szkodą dla interesów społecznych obniża poziom wytwórczości przez pogorszenie jakości wyrobów lub przez zmniejszenie wydajności pracy własnej albo podwładnego personelu; 2) uchylając się od wykonania ciążącego na nim obowiązku przedsiębrania należytych starań o urządzenie techniczne zakładu albo o jego surowce lub towary, pogarsza znacznie stan tych urządzeń albo marnotrawi surowce lub towary, podlega karze więzienia". 
tego „nie można interpretować tak, aby dla przypisania zbrodni z art. 39 m.k.k. konieczne było ustalenie, że sprawca działał z chęci znacznego pogorszenia stanu urządzeń technicznych zakładu. Wystarczy całkowite ustalenie, że sprawca przewiduje możliwość znacznego pogorszenia stanu urządzeń technicznych zakładu i na to się godzi”"23. Kwestia „ustalenia” godzenia się była w istocie fikcją, gdyż - jak wspomniano wcześniej - w państwie komunistycznym zakładano domniemanie świadomości społecznego niebezpieczeństwa czynu.

\section{ZAMIAR EWENTUALNY JAKO INSTRUMENT WALKI Z PRZESTĘPCZOŚCIĄ GOSPODARCZĄ}

Podobnie jak w przypadku przestępstw przeciwko państwu i władzy ludowej, w odniesieniu do przestępstw gospodarczych teoria i praktyka również kładła nacisk na stronę podmiotową czynu, a przede wszystkim umyślność działania. Problemem był jednak ewidentny brak regulacji karnoprawnej nowych stosunków dotyczących własności społecznej i funkcjonowania gospodarki socjalistycznej, zwłaszcza w okresie do wydania dekretów marcowych. Z oczywistych względów kodeks Makarewicza nie rozróżniał karnoprawnej ochrony mienia i gospodarki uspołecznionej. Rewolucyjne przemiany ustrojowo-gospodarcze wymagały jednak wzmożenia ich ochrony, przede wszystkim przed zamachami ,od wewnątrz”, czyli ze strony pracowników sektora uspołecznionego.

Dobrym narzędziem do tego okazał się art. 286 k.k. z 1932 r. ${ }^{24}$ Dzięki szerokiej i w istocie twórczej interpretacji pojęcia „urzędnik” objęto odpowiedzialnością karną z tego przepisu niemal każdego, kto miał jakikolwiek związek z mieniem społecznym, doprowadzając wręcz do rozstrzygnięć absurdalnych ${ }^{25}$. Jednak i to okazało się niewystarczające, bowiem sądy najczęściej w takich sytuacjach stosowały $\S 3$ tego przepisu, czyli nieumyślne przestępstwo urzędnicze. Problemem był w takich przypadkach wymiar sankcji karnej ${ }^{26}$. W przypadku przestępstwa umyślnego widełkowe zagrożenie karą więzienia wynosiło od 6 miesięcy do 5 lat. W przypadku działania nieumyślnego było to „tylko” od tygodnia do 6 miesięcy aresztu. Brak możliwości orzeczenia surowszej kary za przestępstwo nieumyślne,

${ }^{23}$ Wyrok Sądu Najwyższego z dnia 29 marca 1963 r., IV K 745/62, LEX nr 170823.

24 „§ 1. Urzędnik, który przekraczając swą władzę lub nie dopełniając obowiązku, działa na szkodę interesu publicznego lub prywatnego, podlega karze więzienia do lat 5. § 2. Jeżeli sprawca działa w celu osiągnięcia korzyści majątkowej lub osobistej dla siebie lub innej osoby, podlega karze więzienia do lat 10. § 3. Jeżeli sprawca działa nieumyślnie, podlega karze aresztu do miesięcy 6".

${ }^{25}$ A. Stawarska-Rippel, Prawo sadowe Polski Ludowej 1944-1950 a prawo Drugiej Rzeczypospolitej, Katowice 2006, s. 73.

26 T. Cyprian, Odpowiedzialność karna urzędników za przestępstwa gospodarcze $w$ świetle orzecznictwa, „Państwo i Prawo” 1952, z. 11, s. 650. 
które mogło doprowadzić do poważnych strat, skutkował koniecznością skierowania uwagi sądów na konstrukcję zamiaru ewentualnego przestępstwa urzędniczego z Kodeksu karnego z 1932 r.

Jak wskazywali Zbigniew Kubec i Zdzisław Łukaszkiewicz, na początku lat 50. w orzecznictwie Sądu Najwyższego zaczęła zarysowywać się „,dialektyczna koncepcja zmiany ilości w jakość - wynikająca z zasadniczego i bezspornego dla praktyki stwierdzenia - braku wyraźnej granicy między umyślnością (w formie dolus eventualis) a winą nieumyślną (w formie lekkomyślności)" ${ }^{27}$. Polegała ona na przyjmowaniu umyślności (dolus eventualis) na podstawie znacznego rozmiaru szkody, do powstania której mogły doprowadzić nieumyślne działania sprawcy ${ }^{28}$. O przyjęciu umyślności mógł również zdecydować charakter naruszonych obowiązków i specyfika konkretnego stanowiska ${ }^{29}$. Jak bowiem stwierdził Sąd Najwyższy w wytycznych z 11 lipca 1952 r. (KO 145/52):

[...] gdy przy ustaleniu niedoboru stwierdzono niedopełnienie ciążących na oskarżonym obowiązków w zakresie ochrony mienia - stosuje się art. $286 \S 1$ k.k. Niedopełnienie obowiązków może mieć nie tylko postać zaniechania działań nakazanych oskarżonemu przez instrukcje, regulaminy itp., ale może polegać także i na niedopełnieniu czynności wynikających z samej istoty i charakteru stanowiska oskarżonego. Sąd w każdym przypadku oceni, czy zaniedbanie dotyczyło obowiązku tak istotnego, iż dopełnienie go mogło zapobiec niedoborowi [...]. [W rezultacie] ,niedopełnienie czynności wynikających z samej istoty i charakteru stanowiska oskarżonego" należało rozumieć jako co najmniej godzenie się na wyrządzenie szkody w postaci niedoboru [podkr. T.Sz.] ${ }^{30}$.

Jak wynika z przedstawionego stanowiska SN, przyjęcie konstrukcji dolus eventualis z art. $286 \S 1$ k.k. z 1932 r. mogło nastąpić niemal w każdym przypadku. Wszystko zależało od uznania sądu. To sąd określał „świadomość” sprawcy, a nie jego rzeczywisty stosunek do czynu, nawet nie w oparciu o materiał sprawy. „Istota i charakter stanowiska" uzasadniająca ,godzenie się" na niedobór, przy rozciągnię-

${ }^{27}$ Z. Kubec, Z. Łukaszkiewicz, Niedobór gospodarczy w naszym prawie karnym. Uwagi de lege lata i de lege ferenda, „Nowe Prawo” 1952, nr 6, s. 10.

${ }^{28}$, ,...] rozmiary szkody wynikłej z nieumyślnego działania mogą doprowadzić do wniosku, że mamy do czynienia z winą umyślną, ponieważ szkoda wielkich rozmiarów może powstać tylko w warunkach poważnych braków i niewłaściwego stosunku do wykonywanych zadań”. Ibidem.

${ }^{29}$, ,[... [ nie dopełniając ciążącego na nim obowiązku, oskarżony, ze względu na charakter swej pracy i zajmowane stanowisko kierownicze, musiał przewidywać możliwość błędnego zastosowania nowego cennika i wyrządzenie przez to szkody interesowi publicznemu i na to się godził. Czyn taki stanowi przestępstwo przewidziane w art. 286 § 1 k.k.” Wyrok Sądu Najwyższego z dnia 26 stycznia 1951 r., K 1473/50, OSN(K) 1951/3/31, LEX nr 161276.

${ }^{30}$ Uchwała Sądu Najwyższego cała izba SN - Izba Karna z dnia 11 lipca 1952 r., KO 145/52, OSN(K) 1952/4/41, LEX nr 162632. 
tej do granic absurdu wykładni pojęcia „urzędnik” stanowiła fikcję przykrywającą domniemanie winy umyślnej w sprawach gospodarczych.

W połowie lat 60 . w materiałach Ministerstwa Sprawiedliwości wspomniany Zdzisław Łukaszkiewicz tak przedstawił prawidłowy mechanizm przypisywania zamiaru ewentualnego przy przestępstwach niedoborów lub niegospodarności kwalifikowanych z art. $286 \S 1$ k.k. z 1932 r.:

1) [...] oskarżony, który jest kierownikiem sklepu lub magazynierem jako fachowiec ma możliwość przewidywania pewnych sytuacji typowych będących następstwem lekkomyślności lub niedbalstwa;

2) skoro ma tę możliwość, to przewiduje skutki swego zachowania;

3) jeżeli mimo to podejmuje takie działanie, które może skutki szkodliwe sprowadzić, to godzi się na ich wystąpienie ${ }^{31}$.

Własność społeczna miała stać się „święta i nietykalna”, a stosowanie łagodnej - z pogranicza odpowiedzialności dyscyplinarnej - kwalifikacji prawnej niedoborów (tzw. manko) jako przestępstw nieumyślnych (art. $286 \S 3$ k.k. z 1932 r.) do tego staniu nie przybliżało. $\mathrm{Z}$ tych powodów do momentu uchwalenia Kodeksu karnego PRL dolus eventualis z art. $286 \S 1$ k.k. z 1932 r. stanowił ważny element polityki karnej w walce z przestępczością na szkodę gospodarki socjalistycznej32.

\section{ZAMIAR EWENTUALNY JAKO REMEDIUM \\ NA BRAKI USTAWODAWSTWA W DZIEDZINIE PRZESTĘPSTW PRZECIWKO BEZPIECZEŃSTWU W KOMUNIKACJI}

Wraz z dynamicznym rozwojem rewolucji transportowej po II wojnie światowej wzrastał problem karnoprawnej oceny zdarzeń drogowych. W tym szczególnym obszarze szerokie zastosowanie znalazła konstrukcja dolus eventualis przy przestępstwie sprowadzenia niebezpieczeństwa katastrofy ${ }^{33}$. Powstający w czasach początków rewolucji w transporcie drogowym kodeks Makarewicza nie przewidywał, uwzględniających specyfikę zdarzeń drogowych norm prawnych, a odnoszących się do problemu alkoholu w ruchu lądowym i wypadków drogowych. Z tym pierwszym poradzono sobie na podstawie art. 28 ustawy z dnia 10 grudnia $1959 \mathrm{r}$.

${ }^{31}$ Zamiar ewentualny przy przestepstwach drogowych. Fragment referatu wygłoszonego na konferencji sędziów w Sądzie Wojewódzkim w Rzeszowie w dniu 27 marca 1965 r., „Biuletyn Ministerstwa Sprawiedliwości” 1965, nr 3, s. 4.

${ }^{32}$ Ustawa z dnia 19 kwietnia 1969 r. Kodeks karny (Dz.U. Nr 13, poz. 94).

33 T. Cyprian, Wypadki drogowe w 1963 roku w świetle orzecznictwa Sąu Najwyższego, „Ruch Prawniczy, Ekonomiczny i Socjologiczny" 1965, nr 4, s. 74 i n.; T. Rzepecki, Sprowadzenie niebezpieczeństwa katastrofy w komunikacji drogowej (art. 215 \& 1 k.k.), „Zeszyty Problemowo-Analityczne" 1968, nr 8, s. 7 i n. 
o zwalczaniu alkoholizmu ${ }^{34}$. Ten drugi problem rozwiązano dopiero na gruncie Kodeksu karnego z 1969 r.

Karnoprawna ocena większości zdarzeń drogowych, w których dochodziło do ofiar w ludziach i strat materialnych, budziła w okresie 1944-1969 wiele wątpliwości. W praktyce orzeczniczej do tego rodzaju sytuacji sądy stosowały art. 215 (§ 1 umyślne sprowadzenie niebezpieczeństwa katastrofy; § 2 nieumyślne sprowadzenie niebezpieczeństwa katastrofy), art. $230 \S 1$ (nieumyślne spowodowanie śmierci), art. $235 \S 2$ (nieumyślne spowodowanie ciężkiego uszczerbku na zdrowiu), art. 236 $\S 2$ (nieumyślne spowodowanie uszkodzenia ciała lub rozstroju zdrowia do $20 \mathrm{dni}$ ), art. 242 (§ 1 umyślne narażenie człowieka na bezpośrednie niebezpieczeństwo, § 2 nieumyślne narażenie życia człowieka) k.k. z 1932 r. oraz art. 28 i 30 ustawy ,,antyalkoholowej" ${ }^{35}$. Poważnym mankamentem takiej sytuacji-zwłaszcza na gruncie art. $215 \S 1$-było jednak to, że skazanie musiało opierać się na ustaleniu przez sąd, iż sprawca co najmniej godził się na sprowadzenia niebezpieczeństwa katastrofy w ruchu lądowym, a w konsekwencji ,godził się" na ewentualne tragiczne skutki dla siebie samego w przypadku jej nastąpienia. Kwestii tej nie rozwiązywał art. 30 ustawy ,antyalkoholowej”, ponieważ nie zawsze w ruchu lądowym dochodzi do zdarzenia o rozmiarach katastrofy, a ponadto sprawca nie musi być nietrzeźwy, żeby do wypadku lub sprowadzenia zagrożenia katastrofy czy samej katastrofy doszło ${ }^{36}$.

W takiej sytuacji sądy w swojej praktyce dokonywały oceny zdarzeń drogowych przez pryzmat przestępstw nieumyślnych. Lecz podobnie jak w przypadku przestępczości gospodarczej na gruncie art. 286 k.k., w tym przypadku był problem z niską sankcją (art. $215 \S 2$ k.k.) ${ }^{37}$. W celu zaostrzenia polityki karnej należało przekierować orientację sądów na art. $215 \S 1$ k.k., ewentualnie art. 30 ustawy „antyalkoholowej”, właśnie poprzez konstrukcję dolus eventualis.

Z problemem, kiedy po stronie sprawcy można mówić o godzeniu się na sprowadzenie zagrożenia katastrofy w komunikacji, zmierzył się Sąd Najwyższy w wytycznych wymiaru sprawiedliwości i praktyki sądowej w sprawach przestępstw drogowych z dnia 31 sierpnia 1963 r. (M.P. nr 70, poz. 348). Najwyższa

${ }^{34}$ „Art. 28 § 1 . Kto w stanie nietrzeźwości prowadzi pojazd mechaniczny, służący do komunikacji lądowej, wodnej lub powietrznej, podlega karze aresztu do lat 2 lub karze grzywny do 5.000 zł albo obu tym karom łącznie. $§ 2$. Kto w stanie nietrzeźwości prowadzi na drodze publicznej inny pojazd niż określony w $§ 1$, podlega karze aresztu do roku lub karze grzywny do 5.000 zł”.

${ }_{35}$ Projekt kodeksu karnego. Częśś szczególna, Warszawa 1966, s. 56-57.

36 „Kto prowadząc pojazd mechaniczny w stanie nietrzeźwości, sprowadza nieumyślnie niebezpieczeństwo katastrofy w komunikacji lądowej, wodnej lub powietrznej, podlega karze więzienia do lat 5 lub karze aresztu". Ustawa z dnia 10 grudnia 1959 r. o zwalczaniu alkoholizmu (Dz.U. Nr 69, poz. 434).

${ }^{37}$ „Art. $215 \S 1$. Kto sprowadza niebezpieczeństwo pożaru, zalewu, zawalenia się budowli albo katastrofy w komunikacji lądowej, wodnej lub powietrznej, podlega karze więzienia. § 2. Jeżeli sprawca działa nieumyślnie, podlega karze aresztu do roku lub grzywny”. 
instancja sądowa stwierdziła, że choć nie ma możliwości wyliczenia wszystkich przypadków, w których po stronie kierującego pojazdem istnieje zamiar ewentualny sprowadzenia katastrofy w komunikacji, to - jako wskazówkę - polecił sądom rozważenie dwóch sytuacji: pierwszą, kiedy bezpieczeństwo sprawcy było zagrożone w przypadku zajścia katastrofy, drugą, kiedy takiego niebezpieczeństwa nie było. W pierwszym przypadku SN polecił sądom zastanowić się, co skłoniło sprawcę np. do rozwinięcia nadmiernej prędkości. Zdaniem tego organu taką pobudką mogły być w szczególności: chęć ucieczki przed pościgiem lub z miejsca wypadku, chęć popisania się i wyżycia, zmuszenia innych uczestników ruchu do ustąpienia drogi ${ }^{38}$. To z reguły uzasadniało dolus eventualis. $\mathrm{Z}$ kolei ustalenie zamiaru ewentualnego po stronie sprawcy w przypadku, gdy jemu samemu niebezpieczeństwo katastrofy nie zagrażało poważnie, było zdaniem SN mniej problematyczne, ponieważ „może być w większym stopniu oparte na ocenie obiektywnej sytuacji wytworzonej przez sprawcę, gdyż odpada tu element świadomości sprawcy co do narażenia samego siebie na istotne niebezpieczeństwo" 39 . Jak wskazał SN, będą to zazwyczaj „przypadki zajeżdżania drogi lub wymuszania pierwszeństwa przez kierowców dużych i ciężkich pojazdów lub narażania na niebezpieczeństwo jedynie przechodniów"40. Sąd jednak podkreślił, że dla przyjęcia umyślności z art. $215 \S 1$ niezbędne jest umyślne naruszenie zasad bezpieczeństwa w ruchu.

Przyjęcie umyślności sprowadzenia niebezpieczeństwa katastrofy po stronie kierującego pojazdem w stanie nietrzeźwości wymagało zdaniem SN rozważenia stopnia nietrzeźwości oraz wagi naruszonych przepisów lub zasad bezpieczeństwa $\mathrm{ruchu}^{41}$. Z jego wywodów wynikało bowiem, że „wysoki stopień nietrzeźwości i rażące naruszenie przepisów lub zasad bezpieczeństwa ruchu" może wskazywać, że po stronie sprawcy zachodzi umyślność co do sprowadzenia niebezpieczeństwa katastrofy (art. 215 k.k. z 1932 r.), a nie nieumyślność, która uzasadniałaby kwalifikację z art. 30 ustawy o zwalczaniu alkoholizmu ${ }^{42}$. Była to zatem zbliżona sytuacja do tej, jaka istniała w przypadku kwalifikacji z art. 286 § 1 k.k.

Warto podkreślić, a co wynika z pochodzących z 1965 r. materiałów Ministerstwa Sprawiedliwości, że z pewnym zdziwieniem w tym resorcie odbierano sytuację, w której sądy chętniej stosowały konstrukcję dolus eventualis do przestępstw gospodarczych niż do przestępstw komunikacyjnych, a zwłaszcza do art. 215 k.k.

${ }^{38}$ Obwieszczenie Pierwszego Prezesa Sądu Najwyższego z dnia 31 sierpnia 1963 r. o wytycznych wymiaru sprawiedliwości i praktyki sądowej w sprawach przestępstw drogowych, M.P. nr 70, poz. 348.

${ }^{39}$ Ibidem.
${ }^{40}$ Ibidem.
${ }^{41}$ Ibidem.
${ }^{42}$ Ibidem. 
i to pomimo wytycznych $\mathrm{SN}^{43}$. Brak podawanych przyczyn tego stanu rzeczy nie zwalnia oczywiście z próby ich dociekania. Uważam, że sądy bardziej były skłonne uznawać, że ktoś swoim zachowaniem godzi się na wystąpienie szkody Skarbu Państwa, niż że godzi się na utratę życia i zdrowia w efekcie naruszenia zasad bezpieczeństwa ruchu. Wniosek ten wskazuje również na pewien problem ideologiczny i polityczny. Sądy paradoksalnie, bo oznaczało to zaostrzenie represji karnej, swoją postawą dawały do zrozumienia, że życie i zdrowie jednostki było dla nich ważniejszym dobrem od interesów gospodarczych państwa komunistycznego, co w ówczesnej rzeczywistości wcale nie musiało być oceniane pozytywnie.

\section{ZAMIAR EWENTUALNY JAKO NARZĘDZIE WALKI Z ALKOHOLIZMEM}

Przestępstwa polityczne, gospodarcze i komunikacyjne to niejedyne obszary, w których dolus eventualis znalazł zastosowanie. Rzeczywistość powojenna wymusiła również inne spojrzenie na ogólne zasady odpowiedzialności karnej, w tym na kwestię odpowiedzialności karnej za czyn popełniony w stanie wyłączonej bądź ograniczonej poczytalności wywołanej odurzeniem alkoholem. W swoim przemówieniu w Sejmie 19 czerwca 1947 r. Józef Cyrankiewicz powiedział:

[...] katastrofalne zjawisko alkoholizmu w Polsce przybiera formę i charakter zagrażające bezpośrednio utrzymaniu naszej wartości biologicznej, wartości podstawowej dla odbudowy naszego Państwa i Narodu. [...] W obecnym okresie gospodarki planowej i wzmożonej produkcji przemysłowej bardziej niż dawniej potrzeba w Polsce człowieka trzeźwego ${ }^{44}$.

Brak tolerancji dla szerzącego się zjawiska alkoholizmu, a w rezultacie wzrostu przestępczości z tym związanej, był wyraźny. Problemem w wykorzystaniu represji karnej do zwalczania przestępstw o podłożu alkoholowym w ogóle okazał się jednak art. 17 § 2 k.k. z 1932 r. $^{45}$ Wykładnia językowa tego przepisu nie po-

43 „Nie jest więc zrozumiała ta dwutorowość koncepcji zamiaru ewentualnego; inna dla spraw $\mathrm{z}$ art. $286 \S 1$ k.k., inna pełna skrupułów, wahań, restrykcji oraz całego konglomeratu oporów wszelkiego rodzaju - dla spraw drogowych. Czy nie należałoby zatem argumentacji przytaczanej dla zamiaru ewentualnego przy kwalifikacji z art. $286 \S 1$ k.k. stosować również przy przestępstwach drogowych? Przecież »mankowicz«, godząc się na skutki swej lekkomyślności lub niedbalstwa, tak samo, a może nawet bardziej, bo w zasadzie bez wyjątków, naraża także własną osobę na konsekwencje swojego działania, podczas gdy z kierowcą nie zawsze tak jest”. Zamiar ewentualny przy przestępstwach drogowych. Fragment referatu..., s. 4.

${ }^{44}$ A. Stawarska-Rippel, Prawo sadowe Polski Ludowej..., s. 57.

45 „§ 1 . Nie podlega karze, kto w chwili czynu, z powodu niedorozwoju psychicznego, choroby psychicznej lub innego zakłócenia czynności psychicznej, nie mógł rozpoznać znaczenia czynu 
zostawiała wątpliwości, że ten, kto upija się do stanu nieprzytomności, mógł być karany za przestępstwo popełnione w tym stanie tylko wtedy, gdy specjalnie upił się, aby w stanie niepoczytalności popełnić przestępstwo ${ }^{46}$. Przypadki tego rodzaju w praktyce były jednak rzadkie, natomiast nagminnie dochodziło do sytuacji upicia alkoholowego nie w celu popełnienia przestępstwa, do którego następnie dochodziło. Taka sytuacja skutkowała jednak brakiem odpowiedzialności karnej ze względu na niepoczytalność sprawcy.

I w tej sprawie interweniował Sąd Najwyższy. W uchwale z 9 grudnia $1950 \mathrm{r}$. dotyczącej zwalczania przestępstw popełnionych w stanie odurzenia alkoholowego sąd ten podkreślił w propagandowym tonie, że alkoholizm stanowi:

[...] zgubną dla klas pracujących plagę, odziedziczoną po ustrojach eksploatatorskich [...] opóźnia lub utrudnia wykonanie planu sześcioletniego [...] naruszenie chronionego normą prawną zasadniczego interesu społecznego [...] groźną klęskę społeczną, wymagającą w dzisiejszym okresie wzmożonej czujności ze strony organów stosujących represję karną ${ }^{47}$.

Ta wzmożona czujność organów ścigania miała od tego momentu polegać na innym - wykładanym logicznie - rozumieniu wspomnianego art. $17 \S 2$ k.k. (actio libera in causa). Sąd Najwyższy wskazał, że przepis ten obejmuje również przypadki zamiaru ewentualnego:

[...] gdy przez użycie takiej ilości alkoholu, która wywoła stan określony w art. 17 $\S 1$, nie dopełnił ciążącego na nim obowiązku, a upijając się, mógł przy normalnym biegu wypadków przewidzieć możliwość skutku przestępnego lub przestępczości działania i na to się godził (dolus eventualis) ${ }^{48}$.

Jak dosadnie zaznaczył Sąd Najwyższy:

[...] osoby, mające powierzone sobie funkcje, które wymagają szczególnej przytomności umysłu, popełniając przestępstwo w stanie odurzenia alkoholowego, ponoszą pełną odpowiedzialność karną. Tak np. dozorca fabryki lub innego zakładu pracy, który dopuścił do kradzieży, maszynista lub zwrotniczy, który spowodował niebezpieczeństwo katastrofy lub zniszczenia maszyn, nie mogą powoływać się na brak świadomości w chwili popełnienia przestępstwa, wywołany zawinionym odurzeniem alkoholowym ${ }^{49}$.

\footnotetext{
lub pokierować swem postępowaniem. § 2. Przepisu § 1 nie stosuje się do przypadku, gdy sprawca wprawił się umyślnie w stan zakłócenia czynności psychicznej po to, by dokonać przestępstwa".

${ }^{46}$ S. Śliwiński, Polskie prawo karne materialne. Część ogólna, Warszawa 1946. s. 229.

${ }^{47}$ Uchwała Sądu Najwyższego cała izba SN - Izba Karna z dnia 9 grudnia 1950 r., OSN(K) 1951/1/1, LEX nr 166500.

48 Ibidem.

49 Ibidem.
} 
I bynajmniej nie chodziło tylko o przestępstwa przeciwko bezpieczeństwu powszechnemu (przykład zwrotniczego, który w następstwie upicia się nie przestawił zwrotnicy kolejowej, doprowadzając do katastrofy, i powinien zdaniem sądu odpowiadać za umyślne sprowadzenie katastrofy z art. $215 \S 1$ k.k. z 1932 r.), ale w ogóle o zabezpieczenie funkcjonowania całej gospodarki. Umyślność działania (cum dolo eventuali) miała być przyjmowana zawsze, niezależnie, czy sprawca chciał w efekcie odurzenia doprowadzić do przestępstwa, czy nie. Liczył się fakt odurzenia alkoholem, powierzone obowiązki i skutek w postaci ich niedopełnienia w następstwie spożycia alkoholu. Sąd Najwyższy podkreślił bowiem, że takie rozumienie przepisu art. $17 \S 2$ k.k. powinno mieć miejsce w odniesieniu do każdego urzędnika, gdyż

[...] nie wymaga uzasadnienia, iż utrzymanie sił umysłowych i fizycznych w stanie należytej sprawności w czasie wykonywania czynności urzędowych stanowi zasadniczy obowiązek urzędnika, którego nie dopełniając, sprawca działa na szkodę interesu publicznego ${ }^{50}$.

To było istotne wsparcie w możliwości stosowania art. $286 \S 1$ k.k. z 1932 r. wobec będących pod wpływem alkoholu „urzędników”, a w praktyce każdej osoby w jakikolwiek sposób mającej styczność z mieniem społecznym lub gospodarką uspołecznioną.

Powyższy pogląd obowiązywał niemal 20 lat, czyli do wejścia w życie Kodeksu karnego z 1969 r. ${ }^{51}$ Doktryna krytycznie odnosiła się do tej wykładni, sugerując, że było to podejście contra legem, wymagające zmiany legislacyjnej, a nie działalności prawotwórczej Sądu Najwyższego ${ }^{52}$.

\section{ZAMIAR EWENTUALNY JAKO ZAGADNIENIE KODYFIKACYJNE}

Negowanie nieumyślności w odniesieniu do przestępstw o szczególnym znaczeniu dla państwa ludowego oraz powszechne przekierowywanie odpowiedzial-

\footnotetext{
${ }^{50}$ Ibidem.

${ }^{51}$ „Art. $145 \S 1$. Kto, naruszając, chociażby nieumyślnie, zasady bezpieczeństwa w ruchu lądowym, wodnym lub powietrznym, powoduje nieumyślnie uszkodzenie ciała lub rozstrój zdrowia innej osoby albo poważną szkodę w mieniu, podlega karze pozbawienia wolności do lat 3 . § 2 . Jeżeli następstwem naruszenia zasad bezpieczeństwa ruchu jest śmierć, ciężkie uszkodzenie ciała lub ciężki rozstrój zdrowia innej osoby, sprawca podlega karze pozbawienia wolności od 6 miesięcy do lat 8. § 3. Jeżeli sprawca w stanie nietrzeźwości prowadząc pojazd mechaniczny lub inny pojazd dopuszcza się przestępstwa określonego w $\S 1$ lub 2, podlega karze pozbawienia wolności od roku do lat 10". Ustawa z dnia 19 kwietnia 1969 r. Kodeks karny (Dz.U. Nr 13, poz. 94).

${ }^{52}$ W. Świda, Prawo karne. Część ogólna, Warszawa 1967, s. 183-184.
} 
ności na tory zamiaru ewentualnego (przestępstwa komunikacyjne) uczyniły z tego problemu zagadnienie kodyfikacyjne. W doktrynie pojawiały się głosy wskazujące na potrzebę rozważenia innych niż dotychczasowe możliwych rozwiązań w zakresie podziału na winę umyślną i nieumyślną. Na tle płynnych granic zamiaru ewentualnego i świadomej nieumyślności, czyli lekkomyślności w praktyce, duże zainteresowanie wzbudzała koncepcja „trzeciej winy” Löfflera ${ }^{53}$. Polegała ona wyróżnieniu trzech rodzajów winy: zamiaru (Absicht), świadomości (Wissentlichkeit) i winy nieumyślnej (Fahrlässigkeit ${ }^{54}$. Na podkreślenie w tej koncepcji zasługuje wyodrębnienie z winy umyślnej właśnie zamiaru ewentualnego, a z winy nieumyślnej - lekkomyślności i zgrupowanie ich jako jednej kategorii winy, czyli świadomości ${ }^{55}$. Löffler odrzucał z punktu widzenia praktyki zarówno element godzenia się, jak i przekonanie o uniknięciu skutków czynu. Liczyła się według niego tylko świadomość ${ }^{56}$.

Wsparcie doktrynalne, a przede wszystkim ideologiczne, dla zrównywania lekkomyślności z zamiarem ewentualnym w kontekście wspólnej dla nich świadomości stanowiła doktryna ZSRR. Utjewski twierdził m.in.:

W tych przypadkach, kiedy od zachowania się danego człowieka zależą ważne interesy państwowe, kiedy ojczyzna wymaga od niego nie tylko zwykłej uwagi, ale szczególnego, głębokiego przemyślenia i oceny okoliczności, wzięcia pod uwagę wszystkich danych sprawy i powzięcia uzasadnionych postanowień - przestępna lekkomyślność może świadczyć o takim antyspołecznym i niebezpiecznym dla państwa stosunku sprawcy do jego obowiązku, który w pewnych okolicznościach może być uznany nie mniej ciężkim niż przy zamiarze bezpośrednim lub ewentualnym ${ }^{57}$.

Uważał on, że dolus eventualis jest wyższą formą winy od zamiaru bezpośredniego, podając przykład sprawcy, który dla ukrycia kradzieży worka z mąką podpala cały magazyn ${ }^{58}$.

Pomimo uzasadnienia doktrynalnego, ideologicznego, a przede wszystkim praktycznego w pierwszej dekadzie istnienia Polski Ludowej pierwszy projekt Kodeksu karnego materialnego PRL (1951/1956) nie dokonał znaczącej zmiany

53 Jak napisał Stanisław Pławski: „[...] koncepcja Löfflera zrodziła się na gruncie materialistycznej koncepcji winy w walce przeciwko koncepcji idealistycznej. Wprawdzie Löffler nie jest marksistą, ale jego koncepcje są w stosunku do ówczesnej nauki burżuazyjnej koncepcjami postępowymi”. S. Pławski, ,,Trzecia” wina, „Nowe Prawo” 1952, nr 10, s. 26.

${ }^{54}$ S. Pławski, Wina jako problem..., s. 252.

55 Ibidem. T. Cyprian, Wina w projekcie kodeksu karnego..., s. 23.

56 S. Pławski, Wina jako problem..., s. 252.

${ }^{57}$ Ibidem, s. 260, przyp. 47.

58 T. Cyprian, Wina w projekcie kodeksu karnego..., s. 21. 
w podejściu do zagadnienia rodzajów winy ${ }^{59}$. Doktryna podkreślała jednak wprowadzenie materialnego jej elementu w postaci społecznego niebezpieczeństwa, jako m.in. „eliminującego domniemanie, że obywatel zna prawo” oraz rozdzielenie w dwóch przepisach rodzajów winy nieumyślnej, który to zabieg miał wpłynąć na odpowiedni, z reguły wyższy, wymiar kary przy lekkomyślności ${ }^{60}$.

Kwestia „trzeciej winy” pojawiła się również w toku prac nad drugim projektem Kodeksu karnego PRL, który powstał w 1963 r. $^{61}$ Podobnie jak poprzednio, i w tym przypadku nie doszło ostatecznie do zmiany podejścia do Kodeksu karnego z 1932 r. (art. 14 i 16). Uznano bowiem, że to odpowiedzialność z winy nieumyślnej wymaga rozszerzenia i zaostrzenia, tak aby nie nadużywać instytucji zamiaru ewentualnego z k.k. z 1932 r. Zrezygnowano również z modyfikacji dotychczasowego podziału na winę umyślną i nieumyślną poprzez wyparcie z tej pierwszej dolus eventualis i wprowadzenie na jego miejsce lekkomyślności ${ }^{62}$. Należy podkreślić, że w przeciwieństwie do projektu z $1956 \mathrm{r}$. zrezygnowano wówczas z materialnego elementu określającego winę, czyli społecznego niebezpieczeństwa czynu, co ideologicznie i politycznie było bardzo ryzykowne ${ }^{63}$. W toku prac nad trzecim projektem, czyli tym pochodzącym z 1968 r., temat „trzeciej winy” już się nie pojawił $\left(\right.$ art. 7) ${ }^{64}$.

\section{ZAKOŃCZENIE}

W określonych warunkach niuanse dogmatyczne pozwalają przekierować system prawa karnego na zupełnie inne tory. Konstrukcję dolus eventualis traktowano jako remedium na braki legislacyjne przy przestępstwach komunikacyjnych. Z kolei

${ }^{59}$ „Przestępstwo z winy umyślnej zachodzi, gdy sprawca, mając świadomość, że czyn jego jest społecznie niebezpieczny, chce go popełnić albo przewidując możliwość społecznie niebezpiecznego skutku swego czynu na ten skutek się godzi” (art. 8); „Przestępstwem z winy nieumyślnej jest przestępstwo popełnione z lekkomyślności lub niedbalstwa (§ 1). Przestępstwo z lekkomyślności zachodzi, gdy sprawca przewiduje możliwość społecznie niebezpiecznego skutku swego czynu, lecz bezpodstawnie przypuszcza, że tego skutku uniknie (§ 2). Przestępstwo z niedbalstwa zachodzi, gdy sprawca nie przewiduje społecznie niebezpiecznego skutku swego czynu, choć może i powinien to przewidzieć" (art. 9 § 3). Projekt kodeksu karnego Polskiej Rzeczypospolitej Ludowej i przepisy wprowadzajace, Warszawa 1956, s. 7.

${ }^{60}$ T. Cyprian, Wina w projekcie kodeksu karnego..., s. 17 i 23.

${ }^{61}$ Projekt kodeksu karnego, Warszawa 1963.

${ }^{62}$ L. Tyszkiewicz, Projekt kodeksu karnego z 1963 roku na tle ewolucji polskiego prawa karnego w XX wieku [w:] M. Mikołajczyk i in. (red.), O prawie i jego dziejach księgi dwie. Studia ofiarowane Profesorowi Adamowi Lityńskiemu w czterdziestopięciolecie pracy naukowej i siedemdziesięciolecie urodzin, ks. II, Białystok-Katowice 2010, s. 726; M. Szerer, Po wstępnych pracach nad kodeksem karnym, „Nowe Prawo” 1957, nr 7-8, s. 98.

${ }^{63}$ Projekt kodeksu karnego, Warszawa 1963, s. 4.

${ }^{64}$ Projekt kodeksu karnego i przepisów wprowadzających kodeks karny, Warszawa 1968, s. 4. 
przy przestępstwach „urzędniczych” dolus eventualis służył wzmożeniu represji karnej w imię obrony mienia i gospodarki uspołecznionej przed niegospodarnością, niedoborami itp. Najbardziej chyba rażącym przykładem wykorzystania zamiaru ewentualnego było stosowanie kontrrewolucyjnego zamiaru ewentualnego do przestępstw przeciwko państwu (szpiegostwo), stanowiące pochodną odrzucenia w ogóle nieumyślności w tego typu sprawach.

Wspólnymi cechami tego rodzaju praktyk było: (1) instrumentalne traktowanie prawa karnego jako remedium na problemy rzeczywistości; (2) brak pewności prawa, ponieważ rozstrzygnięcia bywały różne i to pomimo wiążących w tym zakresie wytycznych Sądu Najwyższego.

Dowodzi to, że jeśli osiągnięciem cywilizacyjnym było przejście od obiektywizacji odpowiedzialności karnej do jej subiektywizacji, to tego rodzaju postęp nie jest dany raz na zawsze. W określonych warunkach ustrojowych granica między umyślnością a nieumyślnością może nie być bowiem respektowana, prowadząc wręcz do obiektywizacji odpowiedzialności.

Doświadczenia lat 1944-1969 pokazują również, że przyjmowanie przez ustawodawcę tak płynnych (doktrynalnych) rozwiązań prawnych, jak dolus eventualis/ lekkomyślność, może okazać się w pewnych warunkach politycznych niekorzystne, a nawet niebezpieczne dla bezpośrednio zainteresowanych, czyli potencjalnych podsądnych. Taka sytuacja wręcz sprzyja władzy i organom państwa totalitarnego, bowiem pozwala na elastyczne, a w konsekwencji sprzeczne z zasadą nullum crimen sine lege sterowanie polityką karną w sprawach o konkretne rodzaje przestępstw, w zależności od potrzeb. Cienka granica między lekkomyślnością a umyślnością w postaci zamiaru ewentualnego powodowała, że przez ponad 25 lat rozróżnienie czynu umyślnego od nieumyślnego nie opierało się na ustawie, tylko na jego interpretacji sądowej. Symptomatyczne jest również to, że przez tyle lat nie zdecydowano się na nowelizację prawa, aby nie dokonywać wykładni contra legem wspomnianych przepisów. Problem z odróżnieniem świadomej nieumyślności od zamiaru ewentualnego był moim zdaniem zaletą, biorąc pod uwagę wytyczne Sądu Najwyższego.

Doszukując się pozytywów w zjawisku nadużywania dolus eventualis w Polsce Ludowej, należy zwrócić uwagę na dyskusję, która dotyczyła wówczas rodzajów $\mathrm{i}$ form winy. Według mnie była to ze strony przedstawicieli doktryny prawa karnego próba ustabilizowania sytuacji i powrotu do zasady legalizmu, skutkująca ciekawą propozycją w postaci koncepcji „trzeciej winy” Löfflera. 
DOLUS EVENTUALIS AS A REMEDY FOR THE LEGISLATIVE SHORTCOMINGS OF THE CRIMINAL LEGISLATION OF THE PEOPLE'S REPUBLIC OF POLAND BETWEEN 1944 AND 1969 - A LEGAL ANALYSIS

\begin{abstract}
The article presents the use of the construct of recklessness (dolus eventualis) in the doctrine and judicial practice of the People's Republic of Poland between 1944 and 1969 in order to shape - and de facto tighten - the penal policy in cases which involved acts which were classified as unintentional. The paper focuses its ruminations in particular on cases against the political and economic interests of the state, traffic offences and counteracting the negative effects of alcoholism. The conducted analyses indicate that in all these areas the shortcomings of the criminal law system and the subtle (evidence) difference between the deliberate inadvertence (recklessness) and possible intention were used to the detriment of potential perpetrators. These facts clearly confirm the well-known feature of the contemporary system, namely its instrumentalism in the use of criminal law to shape - fight - the negative aspects of the social, economic, and political reality.
\end{abstract}

Keyw ords: criminal law, Polish People’s Republic, dolus eventualis 